\title{
Sistem Pakar Diagnosis Covid-19 Berbasis Mobile Application Android Dengan Metode Certainty Factor
}

\section{Covid-19 Diagnosis Based Android Mobile Application using Certainty Factor Method}

\author{
Imanuel Sinuraya ${ }^{1}$, Agung Triayudi ${ }^{2}$, Ira Diana Sholihati ${ }^{3}$ \\ ${ }^{1,2}$ Universitas Nasional, Jl Sawo Manila Pejaten Pasar Minggu Jakarta 1250, Telp: (021) \\ 7806700, Faks: (021) 780718, Universitas Nasional \\ ${ }^{3}$ Teknik Informatika, Fakultas Teknik Komunikasi dan Informatika, Universitas Nasional \\ Email: ${ }^{1}$ sinurayai68@gmail.com, ${ }^{2 *}$ agungtriayudi@ civitas.unas.ac.id, \\ 3iradiana2803@gmail.com
}

\begin{abstract}
Abstrak
Sistem Pakar merupakan bagian dari kategori umum dari komputer yang dikenal sebagai kecerdasan. Dibuatnya Sistem Pakar untuk mengerjakan domain tertentu. Untuk mempermudah menyimpulkan suatu permasalahan, akan tetapi membutuhkan data yang efisien ke suatu bagian tertentu pada pengetahuan dasar, dan tatacara berpikir manusia untuk mengimplementasikan ilmu pengetahuan pada suatu permasalahan yang diberikan. Pada kecerdasan buatan, sistem pakar merupakan sistem komputer yang meniru kemampuan pengambilan keputusan dari manusia yang ahli bidangnya. Dorongan utama kecerdasan buatan adalah dalam pengembangan fungsi komputer yang terkait dengan kecerdasan manusia, seperti penalaran, pembelajaran, dan pemecahan masalah, untuk membangun sebuah sistem berbasis pengetahuan dalam bidang kedokteran spesifik pada domain untuk bertujuan mendiagnosa Covid-19 yang ditampilkan dalam perangkat mobile, informasi yang cepat dan tepat dari seorang pakar sangat dibutuhkan, dapat dirumuskan suatu masalah berupa diagnosa Covid-19 melalui penerapan sistem pakar berupa input gejala. Hal inilah yang mendorong pembuatan sistem pakar diagnosa Covid-19 dengan menggunakan metode certainty factor berbasis mobile application android.
\end{abstract}

Kata Kunci - Android Mobile Application, Covid-19, Metode Certainty Factor, Sistem Pakar.

\begin{abstract}
Expert Systems are part of a general category of computers known as intelligence. Created Expert System to work on a domain. To make it easier to conclude a problem, however, it requires efficient data to a certain part of basic knowledge, and human thinking procedures to implement knowledge on a given problem. In artificial intelligence, an expert system is a computer system that mimics the decision-making ability of humans who are experts in their fields. The main thrust of artificial intelligence is in the development of computer functions related to human intelligence, such as reasoning, learning, and problem solving, to build a knowledge-based system in the specific field of medicine in the domain for the purpose of diagnosing Covid-19 displayed on mobile devices, information that is quickly and precisely from an expert is needed, can be formulated a problem in the form of diagnosis Covid-19 through the application of an expert system in the form of input symptoms. This is what drives
\end{abstract}


the creation of the Covid-19 diagnostic system using a certainty factor based on Android mobile application.

Keywords -Android Mobile Application, Covid-19, Certainty Factor Method, Expert System.

\section{PENDAHULUAN}

Kesehatan merupakan hal yang penting bagi manusia, namun kebanyakan masyarakat awam kurang begitu memperhatikan masalah kesehatan. Mereka sering menganggap remeh penyakit Covid-19, dan apabila tidak segera ditangani akan menjadi lebih serius penanganannya. Suatu gejala penyakit yang timbul dapat menjadi indikasi suatu penyakit yang akan diderita atau sedang diderita.

Dalam perkembangan teknologi modern maka dikembangkan pula sistem suatu teknologi yang mampu mengadaptasi proses dan cara berfikir manusia yaitu Artificial Intelligence atau Kecerdasan Buatan. Sistem Pakar merupakan bagian dari kecerdasan buatan yang menggabungkan pengetahuan dan penelusuran data yang mampu menyelesaikan masalah layaknya seorang pakar.

Informasi yang cepat dan tepat dari seorang pakar sangat dibutuhkan. Hal inilah yang mendorong pembuatan sistem pakar diagnosa Covid-19 dengan menggunakan metode certainty factor berbasis mobile application android. Dalam perancangannya program ini mengolah informasi dari gejala yang di input. Berupa keluhan atau gejala yang nampak dari dalam tubuh. Diagnosa tadi akan diproses dan menghasilkan diagnosa layaknya fungsi seorang pakar.

Pada penelitian terdahulu dengan judul "Sistem Pakar Diagnosa Penyakit Tanaman Padi Berbasis Web Dengan Forward Dan Backward Chaining" [1] telah membahas sistem pakar yang berkaitan dengan mendiagnosa penyakit tanaman padi berbasis web.

Memberikan informasi mengenai hama penyakit tanaman dan dapat mendiagnosa gejala-gejala penyakit tanaman, khususnya tanaman padi, sekaligus memberikan solusi penanggulangannya, yang nantinya dapat digunakan untuk mengurangi atau memperkecil resiko kerusakan tanaman. Implementasi sistem pakar ini dibuat dengan berbasis Web agar dapat diakses dan dimanfaatkan masyarakat secara luas.

Sistem Pakar Diagnosa Penyakit Tanaman Padi Memberikan informasi mengenai hama penyakit tanaman dan dapat mendiagnosa gejala-gejala penyakit tanaman, khususnya tanaman padi, sekaligus memberikan solusi penanggulangannya, yang nantinya dapat digunakan untuk mengurangi atau memperkecil resiko kerusakan tanaman berbasis web. Penelitian yang lain tentang aplikasi sistem pakar berbasis web telah dilakukan oleh David [2] dengan memanfaatkan Penerapan Fuzzy Moora Pada Sistem Pakar Diagnosa Penyakit Demam Berdarah Dengue, yang dimaksudkan untuk membantu tugas-tugas para dokter serta melengkapi kemampuan para dokter tersebut dalam membuat keputusan yang optimal melalui pengolahan komputer. [3] Penelitian selanjutnya adalah Penerapan Rule Based Forward Chaining pada Sistem Pakar untuk Diagnosa Penyakit Kulit, yang membahas sistem pakar dengan teknik forward chaining yang digabungkan dengan rule based yang digunakan sebagai simulasi diagnosa berdasarkan keluhan atau gejala yang timbul.

Hal yang berbeda pada penelitian ini dengan tiga penelitian terdahulu adalah digunakannya metode certainty factor berbasis mobile application android, dimana pada perkembangan jaman saat ini semua bisa diakses melalui smartphone, client cukup menginstal file apk di smartphone nya yang memudahkan client untuk mendiagnosa Covid-19 sejak dini.

\section{METODOLOGI PENELITIAN}


Metode Penelitian ini berbentuk survey, pengumpulan data yang diambil peneliti yaitu menggunakan pengumpulan data primer berupa wawancara kepada beberapa pakar dalam hal ini adalah Dokter Spesialis Paru-Paru serta melakukan sejumlah pengamatan langsung atau observasi dan Data sekunder berupa dokumen yang berkaitan langsung dengan Covid-19.

Selanjutnya tahapan-tahapan sistematis yang digunakan dalam Metode Certainty Factor digunakan untuk perhitungan nilai kemungkinan $M B, M D$, dan $\mathrm{CF}$, sebagai derajat untuk menunjukkan ukuran kemungkinan diagnosa Covid-19. Program Shell SispakCF berupa installer $a p k$, dapat diinstal pada smartphone android. Untuk pemodelan pada aplikasi kepakaran dengan metode Certainty Factor meliputi tahap pertama yaitu Foreground process, tahap kedua Visible process, tahap ketiga Server process, tahap keempat yaitu Background process dan tahap terakhir yaitu Empty Process. Dengan menggunakan Metode Certainty Factor berbasis Mobile Application Android mempermudah client untuk konsultasi kesehatan dimana mudah diakses oleh masyarakat dengan hasil akhir berupa diagnosa penyakit layaknya seorang pakar.

Instrumen penelitian dengan teknik wawancara dengan beberapa pakar yakni dokter paru dan sebuah alat recorder menggunakan handphone sebagai alat rekaman untuk penyimpanan data pada wawancara dengan para pakar dari Dinas/Instansi bidang Kesehatan dan Dokter spasialis paru. Metode pengujian menggunakan User Acceptance Testing. Hasil penelitian berupa sebab akibat dari indikasi ditemukannya gejala akan suatu indikasi Covid-19 yang disusun dalam web server. Pembuatan aplikasi kepakaran menggunakan bahasa pemrograman java dengan tools SDK platform Android.

\section{HASIL DAN PEMBAHASAN}

\section{Metode Certainty Factor}

Faktor kepastian (certainty factor) menunjukkan ukuran kepastian terhadap suatu fakta atau aturan. Didefinisikan sebagai persamaan berikut:

$\mathrm{CF}[\mathrm{H}, \mathrm{E}]=\mathrm{MB}[\mathrm{H}, \mathrm{E}]-\mathrm{MD}[\mathrm{H}, \mathrm{E}]$, Dimana :

- $\mathrm{CF}=$ Certainty Factor (faktor kepastian) dalam hipotesis $\mathrm{H}$ yang dipengaruhi oleh fakta E.

- $\mathrm{MB}=$ Measure of Belief (tingkat keyakinan) adalah ukuran kenaikan dari kepercayaan hipotesis $\mathrm{H}$ dipengaruhi oleh fakta $\mathrm{E}$.

- $\mathrm{MD}=$ Measure of Disbelief (tingkat ketidakyakinan) adalah kenaikan dari ketidakpercayaan hipotesis $\mathrm{H}$ dipengaruhi fakta $\mathrm{E}$.

- $\mathrm{E}=$ Evidence (peristiwa atau fakta).

- $\mathrm{H}=$ Hipotesis (Dugaan).

Struktur sistem pakar terdiri dari dua pokok, yaitu:

a. Lingkungan Pengembang (development environment)

Lingkungan pengembang digunakan sebagai pembangunan sistem pakar baik dari segi pembangunan komponen maupun basis pengetahuan.

b. Lingkungan Konsultasi (consulatition environment)

Lingkungan konsultasi digunakan oleh seseorang bukan ahli untuk berkonsultasi. 


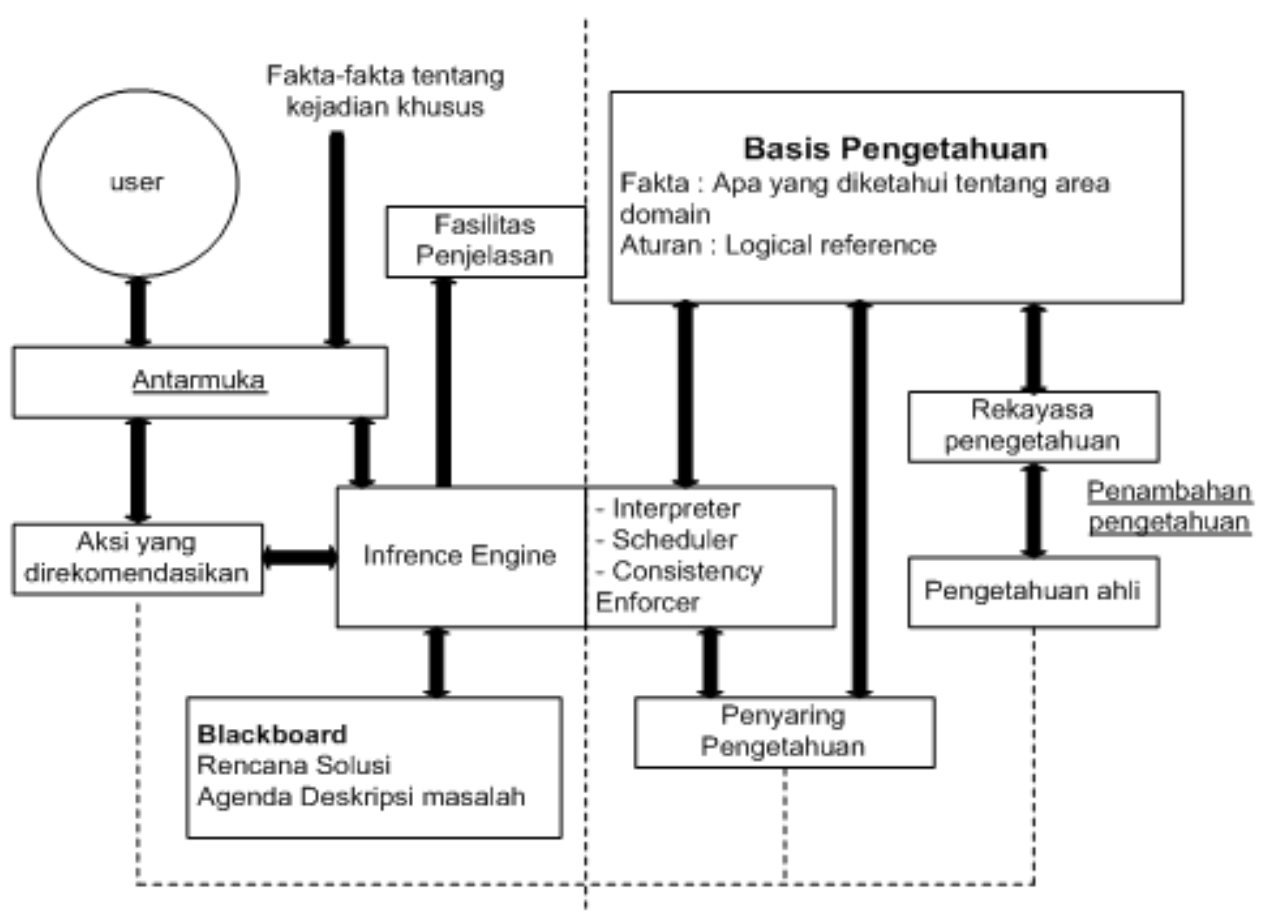

Gambar 1. Arsitektur Sistem Pakar

Komponen-komponen sistem pakar terlihat pada Gambar 1 diatas dan berikut penjelasan nya, yaitu:

1. Subsistem Penambahan Pengetahuan.

Bagian ini digunakan untuk memasukkan pengetahuan, mengkonstruksi atau memperluas pengetahuan dalam basis pengetahuan. Pengetahuan itu bisa berasal dari buku, ahli, basis data, penelitian, dan gambar.

2. Basis Pengetahuan (Knowledge Base).

Berisi pengetahuan yang dibutuhkan untuk memahami, memformulasikan dan menyelesaikan masalah.

3. Mesin Inferensi (Inference Engine)

Program yang berisi metodologi yang digunakan untuk melakukan penalaran terhadap informasi-informasi basis pengetahuan dan blackboard, serta digunakan untuk memformulasikan konklusi.

Ada tiga elemen utama dalam motor inferensi, yaitu:

- Interpreter. Mengeksekusi item-item agenda yang terpilih menggunakan aturanaturan dalam basis pengetahuan.

- Scheduler. Akan mengontrol agenda.

- Consistency enforce. Akan berusaha memelihara konsistenan dalam mempresentasikan solusi yang bersifat darurat.

4. Blackboard

Merupakan area dalam memori yang digunakan untuk merekam kejadian yang sedang berlangsung termasuk keputusan sementara. Ada tiga tipe keputusan yang dapat direkam, yaitu:

- Rencana. Bagaimana menghadapi masalah

- Agenda. Aksi-aksi yang potensial yang sedang menunggu untuk dieksekusi. 
- Solusi. Calon aksi yang akan dibangkitkan.

\section{Antarmuka (Interface)}

Digunakan untuk media komunikasi antar user dan program.

6. Sistem Penyaring Pengetahuan

Sistem ini digunakan untuk mengevaluasi kinerja sistem pakar itu sendiriuntuk melihat apakah pengetahuan-pengetahuan yang ada masih cocok digunakan dimasa mendatang.

Berdasarkan survey dan pengumpulan data yang diambil oleh penulis didapatkan pengetahuan-pengetahuan yang akan menjadi dasar rekayasa pengetahuan. Diantaranya pengetahuan yang didapatkan dari hasil survey sebagai berikut:

- $\quad$ Covid-19

Deskripsi : Penyakit ini terjadi akibat infeksi virus yang menyerang saluran pernapasan. Masa inkubasi flu termasuk singkat. Anda akan mengalami gejala hanya dalam beberapa hari setelah pertama kali terinfeksi. Masa di mana flu paling menular adalah sehari sebelum gejala muncul dan sekitar enam hari berikutnya.

Gejala : : Sakit Tenggorokan

- Sesak Nafas

- Pilek

- Batuk yang berkelanjutan

- Demam

- Menggigil

Obat : Beberapa langkah pengobatan yang bisa dilakukan adalah istirahat yang cukup, banyak minum, serta menjaga tubuh agar tetap hangat. Anda tidak dianjurkan mengonsumsi antibiotik karena obat ini berfungsi untuk membunuh bakteri sedangkan flu disebabkan oleh virus.

Penentu Skala Tingkat Kepercayaan

Untuk menghitung tingkat kepercayaan diperlukan nilai Meansure of Believe (MB) dan Meansure of Disbelieve (MD) dimana nilai-nilai tersebut berada diantara 0-1. Nilai-nilai tersebut kemudian dikelompokkan lagi kedalam 5 index skala yang masing-masing index mencerminkan tingkat kepercayaan tersebut seperti yang terlihat pada Tabel 1 berikut, hal ini untuk mempermudah dalam menentukan tingkat kepercayaan pada saat nilai akhir CF telah didapat.

Tabel 1. Index Tingkat Kepercayaan

\begin{tabular}{cc}
\hline Certain Term & MD/MB \\
\hline Tidak tahu / tidak ada & $0-0.2$ \\
\hline Mungkin & 0.4 \\
\hline Kemungkinan Besar & 0.6 \\
\hline Hampir pasti & 0.8 \\
\hline Pasti & 1 \\
\hline
\end{tabular}


Sistem Pakar Diagnosis Covid-19 Berbasis Mobile Application Android ...

Nilai Kepercayaan dan Tidak Kepercayaan Covid-19

Untuk menghitung nilai Tingkat Kepercayaan (CF) dalam satu diagnosa diperlukan nilai MB dan MD dari gejala kesetiap penyakit yang ada. Berikut adalah nilai MB dan MD gejala Covid-19. Nilai kepercayaan dan tidak kepercayaan suatu gejala dari Covid-19 dapat dilihat pada Tabel 2 berikut.

Tabel 2. Nilai MB dan MD dari Suatu Gejala Covid-19

\begin{tabular}{ccc}
\hline Gejala & MB & MD \\
\hline Sesak Nafas & 0.8 & 0.01 \\
\hline Sakit Tenggorokan & 0.7 & 0.3 \\
\hline Batuk yang berkelanjutan & 0.6 & 0.05 \\
\hline Demam & 0.3 & 0.1 \\
\hline Pilek & 0.4 & 0.1 \\
\hline
\end{tabular}

Menyusun Kaidah Produksi

Untuk mendapatkan hasil dari suatu fakta menggunakan metode $\mathrm{CF}$ digunakan perhitungan nilai MB dan MD dari suatu gejala yang dimiliki suatu penyakit untuk mendapatkan nilai CF. Nilai kepercayaan didapat dari perhitungan nilai MB dan MD. Dari keluhan yang diinput tadi, kemudian akan didapat nilai CF yang tertinggi. Nilai CF tertinggi inilah yang akan dijadikan parameter untuk hasil diagnosa yang dilakukan. Berikut bentuk perhitungan yang dilakukan untuk mendapatkan nilai $\mathrm{CF}$, yaitu:

Diagnosa beberapa gejala satu penyakit:

Jika seorang pasien mempunyai gejala Sesak Nafas, Sakit Tenggorokan, dan Batuk yang berkelanjutan pasien tersebut kemungkinan terinfeksi Covid-19. Nilai kepercayaan untuk gejala Sesak Nafas $\mathrm{MB}=0.8$ dan $\mathrm{MD}=0.01$, untuk gejala Sakit Tenggorokan $\mathrm{MB}=0.7$ dan $\mathrm{MD}=0.03$, dan untuk Batuk yang berkelanjutan $\mathrm{MB}=0.6$ dan $\mathrm{MD}=0.05$. Dari data tersebut maka perhitungan nilai $\mathrm{CF}$ adalah:

CF [covid-19, Sesak Nafas] $=0.8-0.01=0.79$

CF [covid-19, Sakit Tenggorokan] $=0.7-0.03=0.67$

CF [covid-19, Batuk yang berkelanjutan] $=0.6-0.05=0.55$

CF [covid-19, Sesak Nafas^ Sakit Tenggorokan]

$$
\begin{aligned}
& =0.79+0.67 *(1-0.79) \\
& =0.79+0.67 * 0.21 \\
& =0.79+0.1407 \\
& =0.9307
\end{aligned}
$$

CF [covid-19, Sesak Nafas, Sakit Tenggorokan ^ Batuk yang berkelanjutan]

$$
\begin{aligned}
& =0.9307+0.55 *(1-0.9307) \\
& =0.9307+0.55 * 0.0693 \\
& =0.9307+0.038115
\end{aligned}
$$

$=0.968815$

Dengan perhitungan tersebut, maka didapatkan nilai kepercayaan gejala Sesak Nafas, Sakit Tenggorokan dan Batuk yang berkelanjutan untuk Covid-19 adalah 0.968815. 


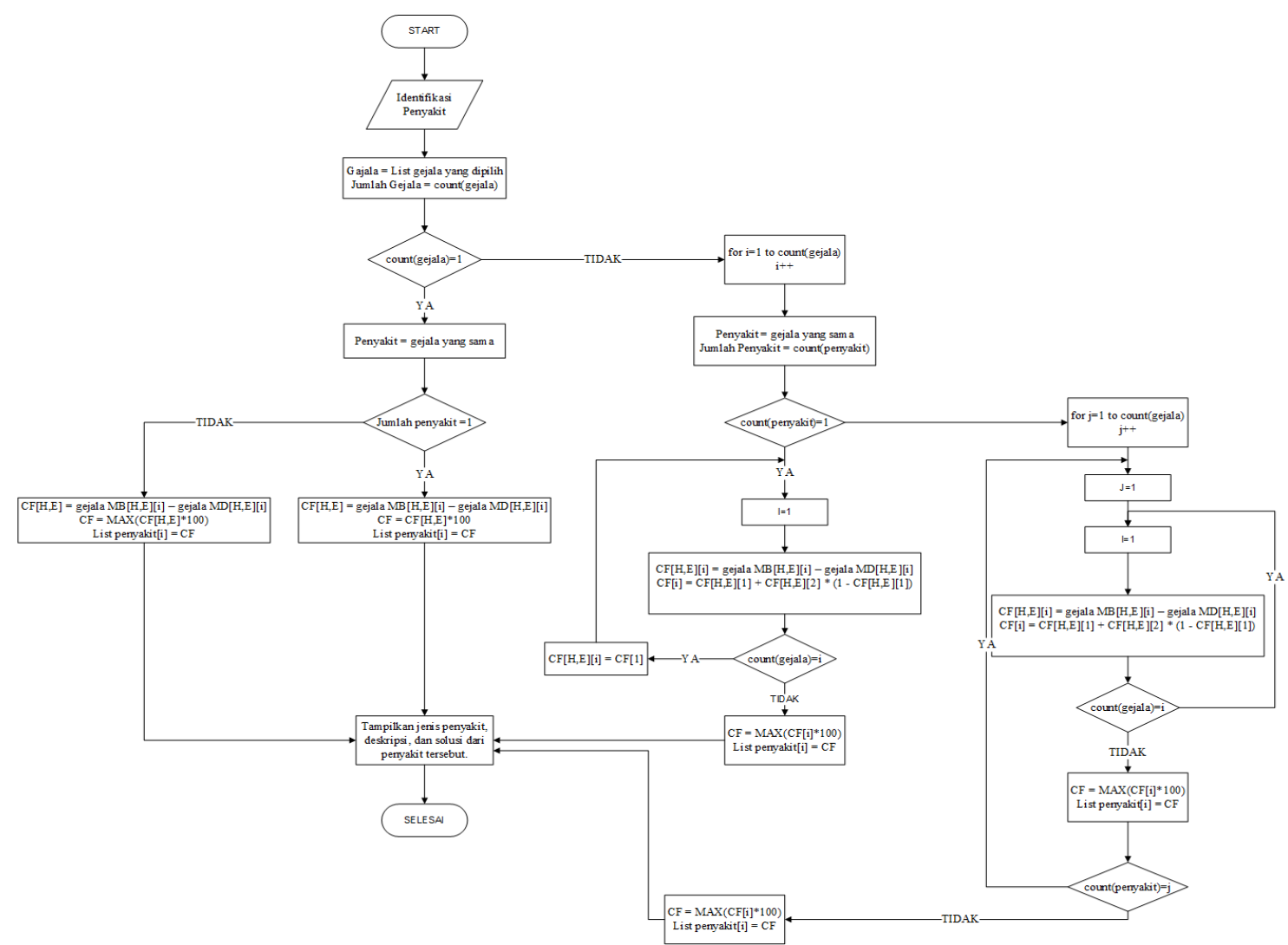

Gambar 2. Flowchart Perhitungan Nilai CF

Halaman Menu Utama Client

Halaman utama adalah tampilan awal. Antarmuka hasil perancangan halaman utama dapat dilihat pada gambar 2 berikut.

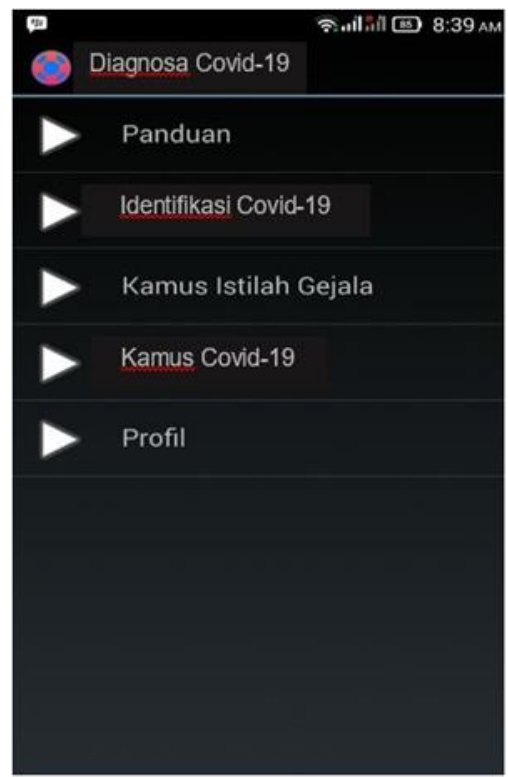

Gambar 3. Antarmuka Menu Utama Client 
Sistem Pakar Diagnosis Covid-19 Berbasis Mobile Application Android ...

Halaman Menu Diagnosa Pada Client

Halaman menu diagnosa merupakan menun yang menampilkan gejala-gejala yang ada pada sistem.

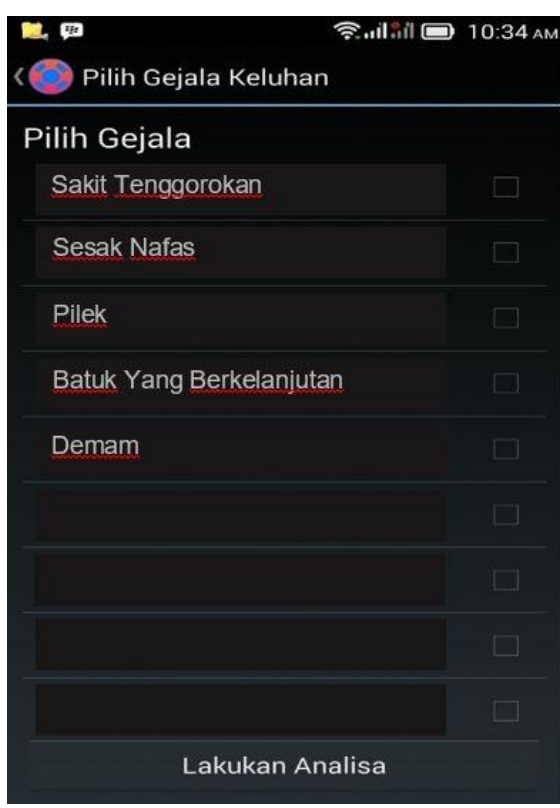

Gambar 4. Menu Diagnosa Covid-19 Pada Client

Pada halaman ini pengguna dapat melakukan proses diagnose untuk memastikan Covid19. Antarmuka perancangan halaman diagnosa dapat dilihat pada gambar 3 berikut.

Halaman Hasil Diagnosa

Pada halaman ini pengguna akan mendapatkan hasil diagnosa serta dapat melihat detail dari Covid-19.

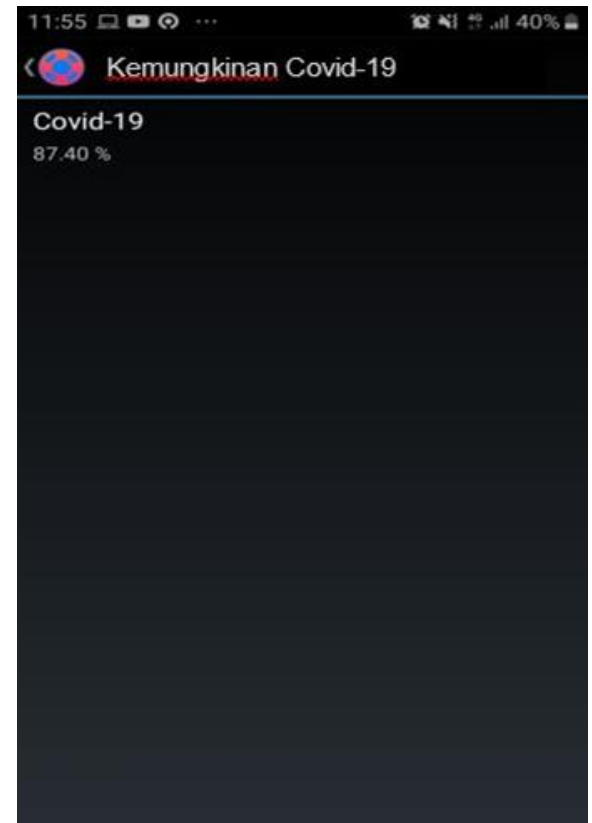

Gambar 5. Hasil Diagnosa Covid-19 Pada Client 
Pada menu utama terdapat lima menu. Fungsi dari masing-masing menu adalah sebagai berikut:

1. Panduan

Merupakan tampilan panduan menggunakan aplikasi diagnosa Covid-19 ini.

2. Identifikasi Covid-19

Merupakan tampilan jenis penyakit.

3. Kamus Istilah Gejala

Merupakan tampilan data keseluruhan gejala-gejala.

4. Kamus Covid-19

Merupakan tampilan keseluruhan Covid-19.

5. Profile

Pada menu ini berisi mengenai profile aplikasi diagnosa Covid-19 ini.

Halaman Form Login Pada Web Server

Seluruh data dari akusis dan representasi pengetahuan disimpan dalam database server, untuk mengaksesnya dengan menggunakan web server sebagai media untuk penyimpanan data.

Form login merupakan sebuah halaman yang pengguna masuk kedalam sistem agar dapat melakukan proses-proses yang sesuai dengan tingkat status kepenggunaannya. Pada aplikasi ini, memungkinan bagi admin untuk input, edit dan menghapus data pakar.

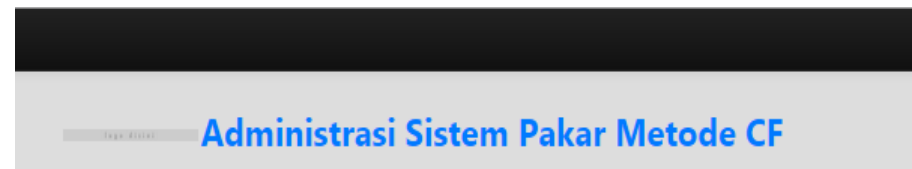

Harap Login terlebih dahulu

Username

Password

Gambar 6. Form Login Pada Web Server

Halaman Menu Penyakit Pada Web Server

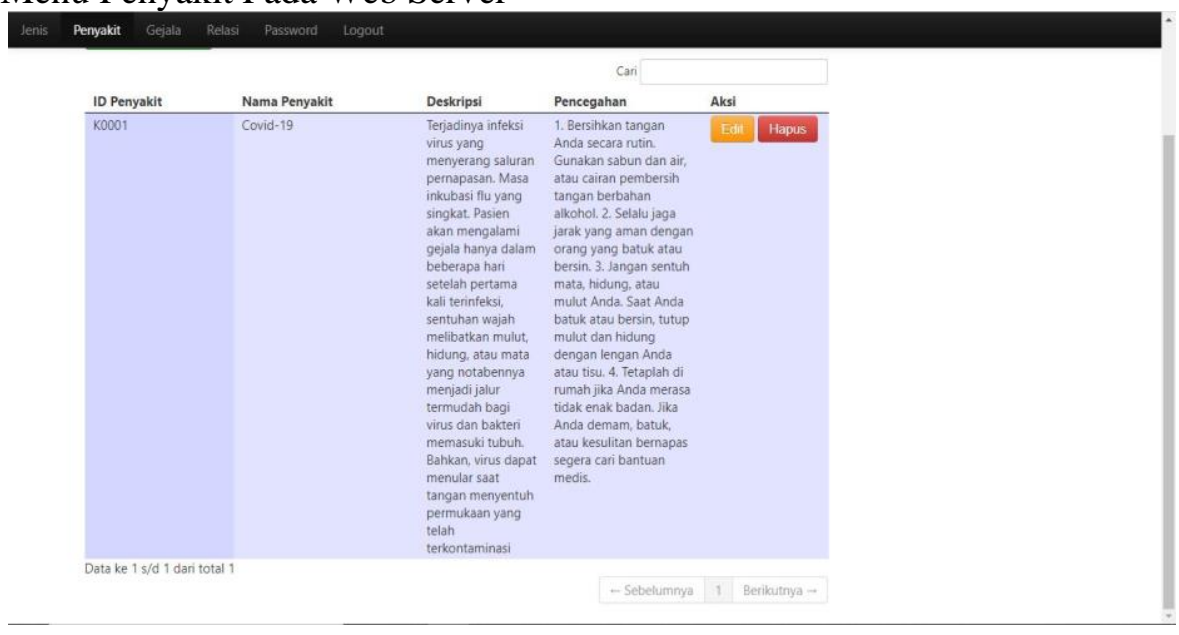

Gambar 7. Halaman Menu Penyakit Pada Web Server 
Sistem Pakar Diagnosis Covid-19 Berbasis Mobile Application Android ...

Halaman menu penyakit merupakan halaman yang menampilkan deskripsi, dan solusi atau pencegahan penyakit yang ada di dalam sistem pakar.

Halaman Menu Gejala Pada Web Server

Halaman menu gejala merupakan halaman yang menampilkan daftar jenis penyakit, nama-nama gejala, dan deskripsi dari gejala penyakit yang ada di dalam sistem pakar.

Jenis Penyakit Gejala Relasi Password Logout

Administrasi Sistem Pakar Metode CF

\section{Buat Gejala Baru}

\begin{tabular}{|c|c|c|c|c|c|}
\hline \multirow{3}{*}{$\frac{\text { Jenis }}{\text { Covid-19 }}$} & \multirow{3}{*}{$\begin{array}{l}\text { ID Gejala } \\
\text { P0001 }\end{array}$} & \multirow{3}{*}{$\begin{array}{l}\text { Nama Gejala } \\
\text { Demam }\end{array}$} & \multicolumn{3}{|l|}{ Cari } \\
\hline & & & Deskripsi & Aksi & \\
\hline & & & $\begin{array}{l}\text { Suhu tubuh di atas } 38 \\
\text { derajat Celsius }\end{array}$ & Edit & Hapus \\
\hline Covid-19 & P0002 & Batuk & $\begin{array}{l}\text { Batuk yang } \\
\text { berkelanjutan }\end{array}$ & Edit & Hapus \\
\hline Covid-19 & P0003 & Sesak nafas & $\begin{array}{l}\text { Nafas pendek, sesak di } \\
\text { dada, dan rasa tidak } \\
\text { mendapatkan cukup } \\
\text { udara }\end{array}$ & Edit & Hapus \\
\hline Covid-19 & P0004 & Sakit Tenggorokan & $\begin{array}{l}\text { Kerongkongan terasa } \\
\text { sakit dan kering }\end{array}$ & Edit & Hapus \\
\hline Covid-19 & P0005 & Pilek & Meriang, menggigil & Edit & Hapus \\
\hline
\end{tabular}

Data ke $1 \mathrm{~s} / \mathrm{d} 5$ dari total 5

Gambar 8. Halaman Menu Gejala Pada Web Server

Halaman Menu Admin Pada Web Server

Halaman admin adalah halaman yang digunakan oleh admin untuk melakukan manajemen pakar.

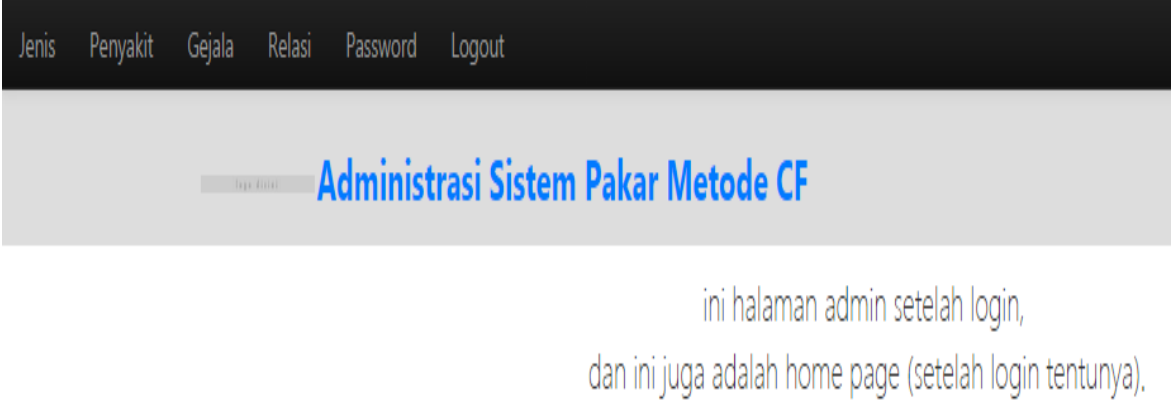

Gambar 9 Halaman Menu Admin Pada Web Server

Pada bagian menu atas halaman admin terdapat enam menu. Fungsi masing-masing menu adalah sebagai berikut:

1. Menu Jenis

Merupakan tampilan data jenis penyakit. 
2. Menu Penyakit

Merupakan tampilan data penyakit.

3. Menu Gejala

Merupakan tampilan data gejala-gejala penyakit.

4. Menu Relasi

Merupakan tampilan relasi antara gejala dengan data penyakit.

5. Menu Password

Merupakan tampilan merubah password admin.

6. Menu Logout

Merupakan tampilan keluar dari halaman admin.

\section{KESIMPULAN}

Setelah dilakukan analisis dan pengujian terhadap Sistem Diagnosa Covid-19 ini, dapat diambil beberapa kesimpulan yaitu, Sistem ini dapat menganalisis jenis Covid-19 berdasarkan keluhan atau gejala yang di input oleh client. Sistem ini juga mampu menyimpan representasi pengetahuan pakar berdasarkan nilai kepercayaan (MB) dan nilai tidak kepercayaan (MD) berupa nilai akhir $\mathrm{CF}$, dan dapat bekerja layaknya seorang pakar dalam mengdiagnosa Covid19. Dengan aplikasi ini client dapat melakukan diagnosa dini terhapat gejala-gejala suatu Covid19 yang dirasakan.

\section{SARAN}

Sistem Pakar Diagnosis Covid-19 Berbasis Mobile Application Android ini masih memiliki banyak kekurangan. Sebagai pengembangan sistem kedepannya agar mendapatkan hasil diagnosa yang lebih baik, data Covid-19 sebaiknya dapat lengkapi. Semakin lengkap data representasi pengetahuan yang ada, maka semakin akurat pula proses diagnosa yang didapat.

\section{DAFTAR PUSTAKA}

[1] Iswanti, S., \& Hartati, S. (2016). Sistem Pakar dan pengembangannya. Yogyakarta: Graha Ilmu.

[2] Yudkowsky, E. (2008). Artificial intelligence as a positive and negative factor in global risk. Global catastrophic risks, 1(303), 184.

[3] Sihotang, H. T. (2017). Sistem Pakar Mendiagnosa Penyakit Kolesterol Pada Remaja Dengan Metode Certainty Factor (Cf) Berbasis Web. Jurnal Mantik Penusa, 15(1).

[4] Kusumadewi, S. (2003). Artificial intelligence (teknik dan aplikasinya). Yogyakarta: Graha Ilmu, 278.

[5] David, (2017). Penerapan Fuzzy Moora Pada Sistem Pakar Diagnosa Penyakit Demam Berdarah Dengue. SEMNASTEKNOMEDIA ONLINE, 5(1), 3-6.

[6] Honggowibowo, A. S. (2009). Sistem pakar diagnosa penyakit tanaman padi berbasis web dengan forward dan backward chaining. Telkomnika, 7(3), 187.

[7] David, (2018). Penerapan Rule Based Forward Chaining pada Sistem Pakar untuk Diagnosa Penyakit Kulit. Konferensi Nasional Sistem Informasi (KNSI) 2018. 